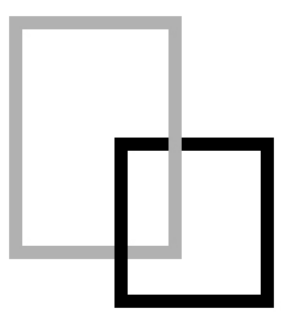

\title{
ZABEZPIECZENIE I EKSPOZYCJA MURÓW ZAMKU W CZŁUCHOWIE - DOŚWIADCZENIA I NOWE PROBLEMY
}

Protecting and displaying walls of the Cztuchów Castle - former practices and current issues

Grzegorz Bukal*

„Wir müssen uns mit Endlichkeit abfinden. Aber es ist unsere Pflicht, das zu tun, was erforderlich ist, um diese Denkmale so lange wie möglich zu erhalten"

Georg Dehio

SUMMARY: The castle of the Teutonic Knights at Człuchów (Schlochau, 1325-1365) was a typical enclosure-plan convent castle. It consisted of a square courtyard with a cloister, four wings and a free-standing tower-keep. The castle was surrounded by a narrow outer ward and dry moats. Large wards protected the castle from the east, west and north.

In 1786-1811 the castle was razed to the ground except the tower, walls of the basements, scarp walls and remains of defensive walls of the eastern ward. The remains of the castle were buried and a neo-gothic church was built in 1820 s on the walls of the northern wing. In 2007-2015 the restoration of the neglected and archaeologically unexplored remains and ruins of the castle was carried out with their adaptive reuse for a local museum. This article presents a brief description of problems relating to the conservation and protection of uncovered and exposed walls.

KEYWORDS: castle, ruins, remains, conservation, protection

Przedmiotem tego tekstu są problemy techniczne zabezpieczenia i ekspozycji odsłoniętych murów zamku w Człuchowie. Prace nad rewaloryzacją pozostałości zespołu zamkowego rozpoczęto w roku 2007, i prowadzono je (według moich projektów koncepcyjnych i częściowo z moim udziałem) do roku 2015․ . Celem artykułu jest konfrontacja stanu obiektu przed

\footnotetext{
* Prof Arch Grzegorz Bukal, Faculty of Architecture, Gdańsk University of Technology https://orcid.org/0000-0001-9254-3069

1 Inwestorem prac była Gmina Miejska Człuchów. Prace realizowane były w oparciu o następujące podstawowe projekty: Projekt koncepcyjny zagospodarowania $i$ adaptacji pótnocnego skrzydła i międzymurza zamku w Człuchowie, aut. G. Bukal, I. Dzierżko-Bukal, A. Kapuściński, 2008; Projekt budowlany przebudowy i adaptacji dziedzińca bramnego zamku w Człuchowie, aut. G. Bukal, I. Dzierżko-Bukal, A. Kapuściński, 2008; Adaptacja wieży zamkowej w Człuchowie na cele turystyczne, aut. J. Belzerowski, „Ap Studio 7”, 2008; Projekt budowlany - Adaptacja pótnocnego skrzydła zamku w Człuchowie, aut. J. A. Rzedzicka, Pro-Bud” Zakład projektowobudowlany, Człuchów, 2011; projekt stanowił wdrożenie Projektu koncepcyjnego zagospodarowania $i$ adaptacji... op. cit. Projekt wnętrz północnego skrzydła zamku w Człuchowie na cele widowiskowe $i$ wystawiennicze, aut. I. Dzierżko-Bukal, 2011; Studium programowo-przestrzenne zagospodarowania i adaptacji dziedzińca Zamku Wysokiego w Człuchowie, załącznik do Programu funkcjonalno-użytkowy - zagospodarowanie dziedzińca zamkowego w Człuchowie, aut. G. Bukal, I. Dzierżko-Bukal, 2013.
} 
pracami ze stanem obecnym, próba oceny zrealizowanych rozwiązań oraz ukazanie nowych problemów powodujących konieczność podjęcia dalszych robót w możliwie bliskim czasie. Tekst stanowi kontynuację dwóch wcześniejszych, przedstawionych na konferencjach ICOMOS oraz opublikowanych w latach 2010 i $2014^{2}$, toteż nie porusza omówionych w nich ogólnych problemów architektoniczno-konserwatorskich oraz funkcjonalnych obiektu.

Zamek w Człuchowie (1325-ok.1365) został prawie w całości rozebrany w latach 17861811. Pozostała jedynie wieża i mury piwnic czworoboku Zamku Wysokiego (bez sklepień), jak również jego mury obwodowe w poziomie przyziemia oraz dolne partie murów obronnych otacząjących zamek. Pozostały również częściowo rozebrane mury przedzamcza wschodniego (tzw. „Kujaw”) oraz mury skarp fos przedzamcza zachodniego. Mury przedzamcza od strony północnej - prawdopodobnie istniejące w postaci reliktów - nie zostały dotąd rozpoznane.

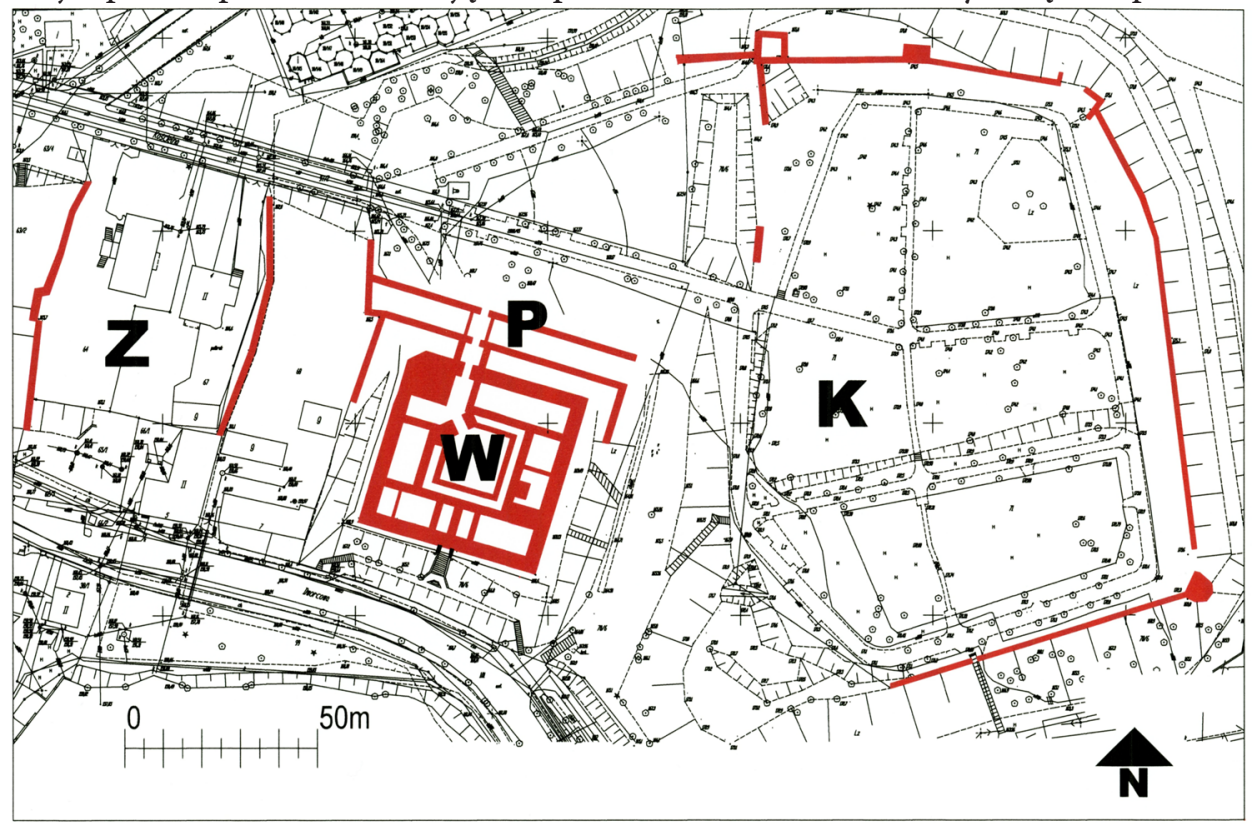

Ryc. 1 Schemat planu zachowanych murów założenia zamkowego (rys. autora): W - zamek wysoki, P - mury parchamu, K - „Kujawy”, Z - przedzamcze zachodnie

W 1. 1820. Przeprowadzono prace porządkowe, podczas których na reliktach skrzydła północnego zbudowano neogotycki kościół. Na terenie „Kujaw” założono cmentarz, i prawdopodobnie wykonano jakieś prace przy pozostałościach murów obronnych. Odtąd,

2 G. Bukal, A. Kapuściński, Problematyka konserwatorska ruin zamku w Człuchowie [w:] Trwała ruina II, problemy utrzymania i adaptacji. Ochrona, konserwacja i adaptacja zabytkowych murów. Red. B. Szmygin. Lublin-Warszawa: Lubelskie Towarzystwo Naukowe, Politechnika Lubelska, Polski Komitet Narodowy ICOMOS 2010, s. 17-28. ISSN 978-83-62596-17-1. Bukal Grzegorz, Dzierżko-Bukal Iwona, Zamek w Człuchowie funkcja zabytku, jako problem konserwatorski [w:] Wartość funkcji w obiektach zabytkowych. Red. B. Szmygin. Warszawa: Polski Komitet Narodowy ICOMOS, Muzeum Pałac w Wilanowie, Politechnika Lubelska 2014, s. 61-80. ISBN 978-83-940280-0-8. 
Zabezpieczenie i ekspozycja murów zamku w Człuchowie. Doświadczenia i nowe problemy

do 2007 r. ruiny zamku - za wyjątkiem wieży - nie były prawdopodobnie przedmiotem poważniejszych działań konserwatorskich, choć dobry stan nigdy nie zasypywanych, kamiennych murów przyziemia czworoboku zamkowego wskazywałby na ich dziewiętnastowieczne naprawy; wykonywano je chyba również wcześniej. Nie prowadzono też badań obiektu, mimo że w końcu XIX w. zamek stał się przedmiotem zainteresowań Steinbrechta, realizującego swoje monumentalne opracowanie architektury zakonu krzyżackiego w Prusach ${ }^{3}$.

Zachowane relikty murów zamkowych można rozpatrywać jako niezależne zespoły pod względem problemów techniczno-konserwatorskich.

\section{Czworobok murów Zamku Wysokiego.}

Zamek założono na planie kwadratu (ok. 47,7 x 47,5 m). Składał się z czterech skrzydeł połączonych krużgankiem oraz wieży głównej", usytuowanej w północno-zachodnim narożniku.

\section{a) Mury skrzydła północnego}

Dwie zachowane kondygnacje skrzydła północnego - piwnica i przyziemie - o wymiarach ok. $28,5 \times 7,5 \mathrm{~m}$ były jednoprzestrzenne, kryte kolebkowymi sklepieniami z lunetami prowadzącymi do okien. Mury o grubości ok. 3,5 i 2,0 m licowano głazami narzutowymi stabilizowanymi małymi kamieniami. Lico murów od strony zewnętrznej wykonano starannie, natomiast od strony wewnętrznej, zasłoniętej przez nieistniejące sklepienia jest ono nieregularne, uzupełniane cegłą. Wypełnisko muru ma charakter mieszaniny głazów i cegieł spajanych zaprawą.

Wiosną 2010 r. stan murów po ich odsłonięciu był dobry, a jedynymi uszkodzeniami były historyczne ślady powstałe przy rozbiórce sklepień.

Zachowanie kamiennego lica zewnętrznego w dobrym stanie było skutkiem jego solidnego wykonania, ale też prawdopodobnie dziewiętnastowiecznych napraw. Powierzchnie wewnętrzne, ukryte przez ok. 200 lat pod zasypem ziemnym, zachowały się dobrze dzięki odcięciu od wpływów atmosferycznych oraz napływu wód gruntowych. Poza oczyszczeniem oraz drobnymi uzupełnieniami cegły i zaprawy nie było więc potrzeby wykonywania tu poważniejszych prac konserwatorskich

Aby zapewnić możliwość ekspozycji autentycznych powierzchni w adaptowanych wnętrzach, zaprojektowano masywne żelbetowe stropy przykrywające kondygnacje, a mury same w sobie stały się eksponatem architektonicznym, nadając obiektowi zamierzony, częściowy charakter trwałej ruiny.

\footnotetext{
${ }^{3}$ C. Steinbrecht, Die Baukunst des Deutschen Ritterrdens In Preussen, IV. Die Or-densburgen der Hochmeisterzeit, Verlag v. J. Springer 1920.

4 Wieża główna, choć pozbawiona oryginalnego zwieńczenia jest w swojej strukturze murów obiektem $\mathrm{w}$ zasadzie nienaruszonym, zachowanym $\mathrm{w}$ dobrym stanie, toteż jej opisywanie nie byłoby uzasadnione w tym tekście, dotyczącym problemów obiektów w stanie ruin. Jej mury są w pełni eksponowane zarówno od zewnątrz, jak i wewnątrz.
} 


\section{b) Mury skrzydeł wschodniego, południowego i zachodniego oraz relikty dziedzińca}

Skrzydło południowe było długim budynkiem, usytuowanym między ścianami wschodnią i zachodnią; wschodnie łączyło je ze skrzydłem północnym, a zachodnie, podobnie jak północne, nie dochodziło do wieży, tak że pomiędzy nimi tworzył się rodzaj dziedzińca, oddzielonego bramą od dziedzińca właściwego. Szerokości skrzydeł były podobne do szerokości skrzydła północnego (ok. 7,5 - 8,0 m). Podczas rozbiórki murów w końcu XVIII w. rozebrano nie tylko sklepienia skrzydeł, ale i ściany przyziemia od strony dziedzińca, pozostawiając tylko zewnętrzne, zamykające czworobok.

Struktura wnętrz skrzydeł jest jednak bardziej skomplikowana. Południowe podzielono pośrodku grubą ścianą poprzeczną na czteroprzęsłowe sale, kryte sklepieniami krzyżowożebrowymi, ale oba przęsła usytuowane od strony ściany środkowej odcięto ścianami, wydzielając małe izbykryte sklepieniami kolebkowymi ${ }^{5}$. W skrzydle wschodnim występująściany poprzeczne, klatki schodowe oraz znaczne występy i pogrubienia wynikające z nierozpoznanej funkcji piwnic. Skrzydło wschodnie nie miało prawdopodobnie podziałów. Krużganek usytuowano na oddzielnych murach równoległych do ścian skrzydeł; struktura tej części jest również dość skomplikowana, zaopatrzona kilka biegów schodów prowadzących do piwnicy.

Muryścian zewnętrznych wzniesiono w technice identycznej jak mury skrzydła północnego. Ceglane mury mają zróżnicowaną strukturę i wątki, ale wykonywane były na ogół starannie.

W roku 2011 r. archeolodzy odsłonili mury skrzydła wschodniego wraz z przyległą partią skrzydła południowego ${ }^{6}$. W przeciwieństwie do murów skrzydła północnego stan murów ceglanych i resztek sklepień był jednak nienajlepszy: poza uszkodzeniami spowodowanymi przez rozbiórki, charakterystyczne były liczne uszkodzenia lica spowodowane korozją cegieł, przejawiającą się w głębokich ubytkach materiału ceglanego przy zachowaniu spoin. Przyczyną tego były zapewne warunki panujące wewnątrz zasypu ziemnego, przez który w okresie około 200 lat przesiąkały wody opadowe; w innych miejscach murów gotyckich uszkodzenia tego rodzaju są rzadkie. Nie powodowało to problemów statycznych, ale wymagało poważnych prac konserwatorskich ${ }^{7}$. W dobrym stanie zachowały się znaczne partie autentycznego bruku dziedzińca. W roku 2013, w wyniku nieoczekiwanego przez władze miejskie dopływu funduszy ${ }^{8}$, spowodowanego sukcesem dotychczasowych prac adaptacyjno-konserwatorskich, rozpoczęto intensywne przygotowania do odsłonięcia pozostałych skrzydeł i dziedzińca zamku.

\footnotetext{
${ }^{5}$ Nie prowadziłem systematycznych badań obiektu i toteż trudno stwierdzić mi czy podział ten jest pierwotny czy wtórny.

6 Badania archeologiczne prowadziła ekipa Instytutu Archeologii Wydz. Historycznego Uniwersytetu Warszawskiego, pod kierunkiem dr Michała Starskiego; (zob. też: Starski Michał, Człuchów - zamek krzyżacki istarościński. http://www.archeo. uw.edu.pl/index.php?id=721, dostęp 15.06.2018). Spodziewano się, że skrzydło to dochodzi do ściany południowej, tak jak na planie zamku rysowanym przez Steinbrechta.

7 W celu tymczasowego, ale długotrwałego (do ok. 10 lat) zabezpieczenia odkrytych reliktów na przełomie 2011/12 r. zbudowano pawilon o konstrukcji drewnianej, z przeziernym dachem (proj. G. Bukal, A. Kapuściński).

8 Zadanie finansowano $\mathrm{z}$ budżetu miasta $\mathrm{z}$ dofinansowaniem $\mathrm{z}$ Regionalnego Programu Operacyjnego Województwa Pomorskiego na lata 2007 - 2013.
} 


\section{Zabezpieczenie i ekspozycja murów zamku w Czhuchowie. Doświadczenia i nowe problemy}

Decyzja o odkryciu i wyeksponowaniu całości zasypanego założenia Zamku Wysokiego była całkowicie uzasadniona z punktu widzenia interesów miasta. Dla Człuchowa - miasta położonego w bardzo malowniczym krajobrazie, ale praktycznie całkowicie pozbawionego (w efekcie walk w 1945 r.) historycznej tkanki miejskiej i nieposiadającego znaczących zabytków architektury, pozostałości założenia zamkowego mają wartość najwyższą.

Ich rewaloryzacja pozwoliła miastu odzyskać ten od 1945 r. niemal dosłownie „zahibernowany” zabytek, czyniąc z niego lokalne centrum kultury i rzadką w skali Polski atrakcję turystyczną. To z kolei pozwala przekładać społeczne zainteresowanie na efekty ekonomiczne.

Kiedy po rozpoczęciu współpracy z władzami miejskimi opracowywano w 2008 r. koncepcję funkcjonowania zamku', kwestia odsłonięcia i ekspozycji piwnic była przedmiotem rozważań, jednakże wobec ograniczonych funduszy i braku pewności ich stałego dopływu w najbliższych latach, nie mogła być poważniej brana pod uwagę. Zakładano więc - jako najbardziej prawdopodobną, racjonalną ekonomicznie i bezpieczną z konserwatorskiego punktu widzenia - jedynie możliwość odsłonięcia skrzydła wschodniego, co istotnie nastąpiło w roku 2011 oraz - po sondażowym przebadaniu archeologicznym - uczytelnienia ukrytych pod zasypem koron murów, tak aby pokazać ich układ. Ewentualne dalsze odsłonięcia mogłyby nastąpić dopiero w bliżej nieokreślonej przyszłości.

Dopływ środków na kontynuację prac miał jednak stronę niebezpieczną, jaką była konieczność przeprowadzenia ich w zbyt krótkim terminie ${ }^{10}$.

Założeniem koncepcji zabezpieczenia ${ }^{11}$ odsłoniętych reliktów było przykrycie przestrzeni odkrytych skrzydeł opartym na konstrukcji stalowej, całkowicie przeziernym (przeszklonym) dachem, umożliwiającym jak najlepszą ekspozycję murów. Dach zabezpieczałby je przed opadami, zapewniając jednocześnie przewietrzanie ruin. Zaprojektowany został z minimalnym spadkiem i w taki sposób, aby nie deformować utrwalonej od dwustu lat sylwety zamku. Stalowa, współczesna konstrukcja miała mieć walor potencjalnej odwracalności, tzn. jej usunięcie nie powodowałoby szkody w strukturze zabytku. Skrzydło zachodnie nie zostało przewidziane do odsłonięcia i jedynie korony murów zostały wyeksponowane.

Zasadę zabezpieczenia zrealizowano właściwie całkowicie zgodnie z przedstawionymi założeniami ${ }^{12}$. Niestety, z niezrozumiałych powodów dokonano pozornie niewielkiej zmiany

\footnotetext{
9 Autorami opracowań byli G. Bukal, I. Dzierżko-Bukal (architektura) oraz A. Kapuściński (konstrukcja).

10 Wykonawcę wyłoniono w drodze przetargu w końcu 2013 r. Opracowanie dokumentacji budowlanej i uzyskanie pozwolenia na budowę miało nastąpić do 31.03.2014; przeprowadzenie badań archeologicznych i opracowanie dokumentacji do 30.09.2014; konserwacja reliktów do 31.10.2014; budowa konstrukcji zabezpieczającej do 31.01.2015 r.

11 Studium programowo-przestrzenne zagospodarowania i adaptacji dziedzińca Zamku Wysokiego w Człuchowie, załącznik do „Programu funkcjonalno-użytkowego pt. Zagospodarowanie dziedzińca zamkowego w Człuchowie realizowane w ramach projektu »Skarb krzyżacki w naszych rękach - prace restauratorskie i adaptacyjne zamku krzyżackiego w Człuchowie na cele kulturotwórcze i turystyczne«", aut. I. Dzierżko-Bukal, lipiec 2013. Studium zawierało projekt koncepcyjny.

${ }^{12}$ Wykonawcą i projektantem przedsięwzięcia - prowadzonego w trybie „Zaprojektuj i wybuduj” - było Polskie Pracownie Konserwacji Zabytków S.A.
} 
projektu koncepcyjnego, stanowiącego podstawę projektu budowlanego. Zmiana polegała na skróceniu (zwężeniu) połaci dachów chroniących relikty, skutkiem czego usytuowane od strony dziedzińca ściany odsłoniętych piwnic ulegają zalewaniu podczas silnych opadów. Wada ta będzie oczywiście możliwa do usunięcia, ale jeśli nie nastąpi to w możliwie krótkim czasie, dojdzie do uszkodzeń struktury murów w tej strefie. (Ściany położone po przeciwnej stronie są chronione dobrze, a lokalne występowanie glonów w miejscach stale zacienionych jest zjawiskiem naturalnym, możliwym do likwidacji w trybie konserwacji bieżącej.)

Innym problemem wymagającym rozwiązania są niedostateczne zabezpieczenia odkrytych koron reliktów murów krużganków. Jest to wiele stosunkowo drobnych partii o dość trudnych do ochrony, nieregularnych powierzchniach poziomych i skośnych, częściowo zniszczonych podczas rozbiórek oraz w sposób naturalny. Zabezpieczenia wykonane metodami konserwatorskimi, wyłącznie z użyciem preparatów i współczesnej cegły „gotyckiej” niestety bardzo szybko zawodzą i będą wymagały zmian. Dowodzi to jednoznacznie słabej jakości produkowanej w Polsce cegły, jak i nadmiernej wiary konserwatorów-technologów i konserwatorówurzędników w osiągnięcia (nietaniej) chemii budowlanej wytwarzanej przez „renomowanych” producentów (przy pełnej analogii do działalności koncernów farmaceutycznych).

Pod względem funkcjonalnym zrealizowana eskpozycja murów działa jednak całkowicie prawidłowo.

Usunięcie zasypu ziemnego i odsłonięcie reliktów było zabiegiem uzasadnionym. Gdyby decyzji tej nie podjęto, pozostałyby one prawdopodobnie na długi czas nierozpoznanym i niewykorzystanym źródłem wiedzy o architekturze zamku ${ }^{13}$. Również wartość użytkowa zabytku, w sensie jego przydatności edukacyjnej i roli społecznej byłaby znacznie mniejsza.

Okolicznością niekorzystną był jednak sposób finansowania przedsięwzięcia, stawiający władze miasta w sytuacji bez alternatywy - wręcz szantażu: „teraz albo nigdy”. Skutkowało to pośpiechem i błędami popełnionymi podczas realizacji. Sposób finansowania wszystkich prac prowadzonych w zespole zamkowym był zresztą podobny - uwarunkowany ograniczeniami finansowymi niewielkiego miasta, niepewnością uzyskiwania środków zewnętrznych na poszczególne etapy prac i obowiązującymi procedurami ich rozliczania $\mathrm{w}$ napiętych terminach. Presja czasu prowadziła do konieczności obierania dróg „na skróty” - dotyczącej kolejności działań, uproszczeń badań i dokumentacji itp. w rezultacie - niepotrzebnych błędów. Innego rodzaju problem stwarzała konieczność podporządkowywania się procedurom przetargowym, których wadą systemową jest wymienność i przypadkowość wykonawców robót, o zróżnicowanych kwalifikacjach. Ujawniały się przy tym także „obiektywne ograniczenia rynkowe” w dziedzinie możliwości pozyskiwania w Polsce wykonawców robót budowlanokonserwatorskich i rzemieślników oraz nadzoru budowlanego na odpowiednim poziomie, co okazywało się bardzo trudne lub nawet niemożliwe. Odnosi się to także do opracowania

13 Interesujące, że plan podziemi zamku narysowany przez Steinbrechta (op. cit., s. 32) okazał się całkowicie fantastyczny (jak i wywiedzione z niego „rekonstrukcje” wyższej kondygnacji), co dowodzi „naukowej kreatywności” tego skądinąd poważnego i zasłużonego badacza architektury krzyżackiej, ale i pełnego inwencji twórczej architekta-konserwatora, realizującego w czystej formie metodę „restauracji stylistycznej”. 


\section{Zabezpieczenie i ekspozycja murów zamku w Człuchowie. Doświadczenia i nowe problemy

dokumentacji, która w przypadkach takich jak w Człuchowie powinna być nie tylko weryfikowana standardowo, zgodnie $\mathrm{z}$ obowiązującymi przepisami, ale także oceniana przez ekspertów niezależnych od jednostek projektujących.

Działania podjęte w zamku wCzłuchowie dowodzą,że decyzje o tak rozległych odsłonięciach powinny być podejmowane bardzo ostrożnie, a procesy badań i zabezpieczeń rozłożone na lata. Ponadto, należy brać pod uwagę zakres odsłonięć i ich celowość w stosunku do kosztów zabezpieczeń i spodziewanych wyników naukowych czy rzeczywistej atrakcyjności zabytku. Zwłaszcza tam gdzie - jak w Człuchowie - średniowieczne relikty zostały wyeksplorowane i gdzie nie można spodziewać się znaczących znalezisk archeologicznych.

\section{c) Przedbramie i mury obwodu zewnętrznego.}

Zamek Wysoki otaczał z czterech stron mur obronny i fosy. Międzymurze (parcham) tworzyło typowy dla zamków konwentualnych taras wyniesiony ponad poziomy dna fos o ok. 5-10 m. Mury skarpowe fos były jednocześnie murami obronnymi. Przed frontem północnym znajdował się następny parcham, a przed nim fosa.

Relikty murów od strony północnej, najlepiej zachowane, wraz z reliktami murów przedbramia odsłaniano w latach 2008-2009. Uwidoczniły się dwa ciągi murów od północy oraz niewielkie relikty muru tworzącego jednocześnie oskarpowanie fosy wschodniej. Południowego odcinka muru nie badano.

Lico dolnych partii murów wzniesiono w typowej technice, z głazów narzutowych, starannie klinowanych małymi kamieniami, a czasem cegłami. Mur zewnętrznego parchamu był od strony fosy oblicowany cegłą. Wszystkie zachowane relikty były w dobrym stanie.

Wschodni, a prawdopodobnie również południowy odcinek muru zachowały się w podobnym stanie niskich reliktów, obecnie całkowicie zasypanych. Doprowadzenie murów do stanu umożliwiającego ekspozycję nie wiązało się z poważnymi problemami. Wymagały tylko stosunkowo drobnych napraw i uzupełnień. Zdecydowano się jednak na całkowite oblicowanie cegłą muru zewnętrznego. Zapewniło to odsłoniętemu wypełnisku ochronę, choć przy dość wyrównanej koronie warstwy licowej nadawało obiektowi początkowo charakter zbyt wyraźnego preparatu. Korony muru zabezpieczono warstwą kamieni i zaprawy wodochronnej. W podobny sposób zabezpieczono prawdopodobnie w XIX w., korony muru odcinka wschodniego. Miejscowo zastosowano też przekładki z blachy ołowianej. Mury te odsłonięto i wyeksponowano. (Zdecydowano się jednak zakopać odkryte relikty murów przybudówek nowożytnych $\mathrm{z}$ fragmentami posadzki, zlokalizowane w narożniku północno-zachodnim.)

Na znacznej powierzchni przestrzeni przedbramia zachował się oryginalny średniowieczny bruk z wyraźnym rynsztokiem. Ze względu na znaczne ubytki musiał jednak zostać zasypany i pokryty współczesną kostką granitową. Bruk ten zachował się również w przestrzeni miedzy wieżą, a skrzydłem północnym (dziedzińcu bramnym), stanowiącej obecnie sień obiektu. Jego odkrycie przez archeologów nastąpiło jednak dopiero po wykonaniu projektu głównej klatki schodowej, która wraz z dźwigiem miała wypełniać przestrzeń dziedzińca bramnego. 
Aby uniknąć zniszczenia bruku w stopniu większym niż było to konieczne do posadowienia dźwigu, przeprojektowano całkowicie fundament klatki schodowej i posadowiono ją na czterech wierconych palach, ratując, a częściowo pozwalając na odtworzenie nawierzchni brukowej. Ze względu na jej znaczną nierówność, aby umożliwić bezpieczne poruszanie się (droga ewakuacyjna) pokryto bruk w pasie pomiędzy schodami, a dźwigiem przeszkloną podłogą, zapewniając jego ekspozycję.

Z perspektywy roku 2018 stan zachowania odsłoniętych murów w kilka lat po zakończeniu prac nie powinien budzić niepokoju. Wprawdzie wkrótce po wykonaniu robót na odtworzonym licu ceglanym pojawiły się wykwity soli wypłukiwanych z nowej zaprawy, zostały one dość szybko i relatywnie skutecznie usunięte. (Przyczynę powszechności tego problemu w Polsce - bardziej estetycznego niż konserwatorskiego - należałoby prawdopodobnie upatrywać w jakości gotowych „zapraw konserwatorskich” oferowanych na rynku, względnie w swoistej „optymalizacji” ich składu przez firmy wykonawcze.)

Nieco bardziej niepokojące jest zawilgocenie warstwy licowej występujące w sąsiedztwie gruntu. Jest skutkiem braku izolacji poziomej i będzie wymagało napraw. Nie jest jednak na razie niebezpieczne dla zabytku.

Zabezpieczenie koron muru warstwą kamieni i zapraw wydaje się na razie skuteczne.

\section{d) Mur skarpowy fosy zachodniej}

Mur skarpowy fosy zachodniej jest wprawdzie zachodnim murem zewnętrznym Zamku wysokiego, ale ze względu na nieporównanie pełniejszy stan zachowania można omawiać go oddzielnie. Mur tworzy prostą kurtynę, ale jej północny kraniec (na wysokości zewnętrznego parchamu) jest nieco wysunięty ku zachodowi. Struktura muru jest podobna do pozostałych murów zewnętrznych zamku (i innych murów obronnych wznoszonych w tym regionie w okresie średniowiecza). Mur zachował się na długości ok. 60 m. Jego obecna wysokość wynosi ok. 10 $\mathrm{m}$ od dna fosy; pierwotna wysokość muru jest nieznana gdyż nie zachowały się pozostałości oryginalnej korony. Również jej kształt jest nieznany.

Partię cokołową, o wysokości ok. 4,5 m wzniesiono z kamieni narzutowych o zróżnicowanej wielkości (od kilkudziesięciu do ponad $100 \mathrm{~cm}$ ) oraz częściowo z kamienia łamanego. W celu uszczelnienia i stabilizowania większych kamieni lub wyrównywania warstw zastosowano drobniejsze kamienie i okrzeski.

Partię górną wymurowano z cegły gotyckiej o wymiarach ok. 32 x 15 x $9 \mathrm{~cm}$, dobrej jakości, ale w dość niestarannym wiązaniu (gotyckim). Grubość muru na wysokości obecnej korony wynosi ok. $90 \mathrm{~cm}$. Grubość dolnych partii muru jest nieznana.

W roku 2008 mur znajdował się w stanie ruiny o różnym stopniu zachowania. Cały południowy odcinek muru (ok. 40\% długości) został rozebrany w nieznanym czasie, po czym tylko jego dolną część odbudowano niedbale, z mniejszych kamieni.

Obecne zwieńczenia muru są efektem zniszczeń i doraźnych napraw. W niektórych częściach partii górnej na warstwie cegieł ułożono warstwę ochronną z niewielkich kamieni narzutowych 


\section{Zabezpieczenie i ekspozycja murów zamku w Człuchowie. Doświadczenia i nowe problemy

na mocnej zaprawie.

Mur nie wykazywał deformacji ani spękań. W zachowanej części lico kamienne partii cokołowej zachowało się właściwie w 100\%, w zasadzie bez uszkodzeń, tylko z niewielkimi ubytkami. Oryginalna warstwa licowa partii górnej (o grubości $1 \frac{1}{2}$ cegły) zachowała się w części odkrytej muru tylko w ok. $30 \%$. Utrata lica nastąpiła w wyniku procesów erozyjnych, a może również celowych rozbiórek.

Jako zasadę przyjęto konserwację obiektu $\mathrm{w}$ stanie trwałej ruiny $\mathrm{z}$ minimalizowaniem ingerencji. Korona muru okazała się trwała i nie wymagąła przemurowań, mimo dość znacznego zniszczenia powierzchni cegły; decydująca była dobra jakość użytych materiałów

Partie pokrytekiedyś ochronną warstwą kamienia, jaki ona sama, okazały się nieoczekiwanie trwałe, choć zakładano potrzebę jej wymiany lub poważnych napraw. Lico kamienne uzupełniono odzyskanymi oryginalnymi kamieniami; lico ceglane miejscowo kotwiono i tylko częściowo uzupełniono częściowo rozbiórkową cegłą gotycką, częściowo cegłą współczesną o zbliżonych parametrach, na zaprawach przygotowywanych na miejscu i konserwatorskich do spoinowania. Znaczne partie pozbawione oryginalnego lica jedynie zabezpieczono metodami konserwatorskimi. Zapewniło to zachowanie autentyzmu obiektu, którego obraz nie różni się znacznie od stanu zarejestrowanego przez Steinbrechta.

Wizja lokalna przeprowadzona wiosną 2018 r. (wprawdzie nie z rusztowań) nie wykazała nowych uszkodzeń czy symptomów awarii. Jedynym zjawiskiem niekorzystnym jest porastanie półek i występów przez trawy i inne drobne rośliny, które powinny być usuwane okresowo w ramach konserwacji bieżącej.

\section{Mury „Kujaw”}

Płaski teren „Kujaw otaczają od południa wschodu i północy trzy odcinki muru o łącznej długości ok. $300 \mathrm{~m}$, usytuowane na krawędzi skarp opadających ku suchym fosom. W narożniku północno-wschodnim zachowały się relikty bramy; w odcinku północnym - pozostałości dwóch prostokątnych baszt, a w narożniku południowo-wschodnim - jednej, okrągłej. Grubości murów wynosily ok. 120-200 cm przy powierzchni terenu. Struktura murów przypomina pozostałe wznoszone w Człuchowie Lica wykonano z kamieni narzutowych o różnej wielkości, stabilizowanych małymi kamieniami; wypełnisko zawiera kamienie, gruz i cegły.

Do 2007 r. mury zachowały się w stanie ruin o zróżnicowanej wysokości od 0,5 do 5,0 $\mathrm{m}$ powyżej poziomu terenu. Mury utraciły górne partie wykonane prawdopodobnie z cegły (podobnie jak w innych murach). Największym problemem były jednak ubytki lica, sięgające na głębokość $50-60 \mathrm{~cm}$, i obejmujące do $100 \%$ powierzchni w wielu partiach. Odsłonięte wypełnisko, narażone na działanie czynników atmosferycznych erodowało w wyniku niszczenia zaprawy wapiennej i mur dosłownie rozsypywał się. Jeden z fragmentów muru na odcinku południowym wykazywał lekkie wychylenie na zewnątrz.

Podstawowym problemem wiążącym się z realizowaniem zabezpieczeń konstrukcji murowych tego rodzaju jest brak możliwości powstrzymania naturalnych procesów niszczenia 
oraz skutecznego długotrwałego zabezpieczenia budowli. Osiągnięcie stanu gwarantującego pełne zabezpieczenie wymagałoby odbudowy w stopniu całkowicie niszczącym autentyzm zabytków. Zdecydowano się ${ }^{14}$ na rozwiązania pośrednie. Tam gdzie było to konieczne i możliwe odtworzono lica kamienne, używając oryginalnego materiału kamiennego. Oczywiście wbudowywanie poszczególnych kamieni w miejsca ich oryginalnej lokalizacji było poza wyjątkami niemożliwe. Głazy stabilizowano mniejszymi kamieniami, starając się naśladować technikę oryginalną, co było jednakże trudne dla wykonawców i udawało się $\mathrm{z}$ różnym powodzeniem. Udało się zachować $\mathrm{w}$ miarę naturalny charakter ruin, jednakże bez poprzedniego, malowniczego „dramatyzmu”.

Większość powierzchni i koron murów starano się tylko stabilizować i uzupełniać poważne ubytki stosując kamienie i zaprawy. Nie udało się uniknąć pewnych przewidywanych rozbiórek górnych partii. Jedynym obiektem odbudowanym w poważniejszym stopniu - choć utrzymanym nadal $\mathrm{w}$ stanie ruiny była jedna $\mathrm{z}$ baszt, na której założono taras widokowy dostępny z dostawionej, stalowej klatki schodowej.

Obecnie (wiosną 2018) zrealizowane zabezpieczenia wydają się spełniać swoje zadania. Na razie brak poważniejszych uszkodzeń, choć obserwuje się symptomy nowych, drobnych, które za jakiś czas będą wymagały ponownych interwencji1 ${ }^{15}$.

\section{Mury skarpowe przedzamcza zachodniego}

Zachowana struktura oskarpowania fosy wschodniej jest jednolita pod względem techniki budowy; brak cech wskazujących na powstawanie muru w różnych - a w każdym razie odleglejszych chronologicznie fazach. Konstrukcja muru przypomina konstrukcję muru „Kujaw” oraz dolnej, kamiennej partii wschodniego muru skarpowego fosy zachodniej. Mur ma długość ok. $60 \mathrm{~m}$. Oba lica wykonane są z warstw z kamieni narzutowych, i łamanych, o różnej wielkości (do ok. $100 \mathrm{~cm}$ ) i kształcie, czasem docinanych w celu wyrównania lica. Pomiędzy licami ułożono wypełnienie z układanych warstwami nieregularnych kamieni, wymieszanych z zaprawą wapienną i gruzem ceglanym. We wnętrzu muru są też puste przestrzenie oraz kamienie niespojone zaprawą. Stan ten nie wynika z ubytków zaprawy, ale pierwotnej technologii budowy muru. Obok drobnych kamieni klinujących większe głazy, w szczelinach zachowały się również wbudowane cegły ${ }^{16}$. Mur budowany był dość niestarannie; mogło to być efektem pośpiechu. Staranniejszy, warstwowy układ kamieni zaobserwować można jedynie miejscowo

14 Projekt budowlany zabezpieczenia i konserwacji muru obronnego podzamcza zamku w Człuchowie, aut. G. Bukal, A. Kapuściński, 2008.

${ }^{15}$ Naprawy wymaga jedynie łęk dziewiętnastowiecznej „Bramy Luizy”, którego zabezpieczenie od góry warstwą zaprawy wodochronnej okazało się nietrwałe i powinno zostać wkrótce zamienione na warstwę bardziej pewnej hydroizolacji.

16 Interesujące jest jednak, ze obok cegieł o dużych wymiarach („gotyckich” - główka ok. 15 x $9 \mathrm{~cm}$ ) zachowały się również cegły małe (o wys. ok. $6 \mathrm{~cm}$ ), co świadczyłoby o dokonywaniu napraw muru w okresie nowożytnym; może także w XIX czy nawet początku XX w. (W nasypie przy murze zaobserwowano także gruz ze śladami zapraw cementowo-wapiennych.). 
Zabezpieczenie i ekspozycja murów zamku w Człuchowie. Doświadczenia i nowe problemy

- w zachowanych partiach lica czy wypełniska. W znacznych partiach muru układ jest jednak nieregularny.

Zaprawa jest dobrej jakości i w wielu miejscach charakteryzuje się wysoką wytrzymałością, mimo zawilgocenia, pokrycia glonami i długotrwałego oddziaływania czynników powodujących erozję i korozję (wilgoć, wody opadowe, wiatry, oddziaływanie roślin i porostów).

Mur posadowiono bardzo płytko, zaledwie ok. 0,8 m poniżej poziomu przylegającego terenu. Pierwotna grubość muru na wysokości ok. $2 \mathrm{~m}$ ponad poziomem terenu wynosiła ok. $160 \mathrm{~cm}$. Fundament nie ma wyodrębnionej ławy ani pod względem charakterystyki budulca, ani grubości muru. Dół fundamentu tworzy warstwa niewielkich kamieni przykrytych jedną warstwą cegły lub gruzu ceglanego, na której ułożono warstwy kamieni ${ }^{17}$. Prawdopodobnie w taki sposób fundamentowano również inne, podobne mury zamku.

Górna partia muru wykonana była $\mathrm{z}$ cegły ${ }^{18}$, ale nie wiadomo jak wyglądało jej oryginalne zwieńczenie.

Wbudowany materiał ceglany dowodziłby przeprowadzania napraw muru $\mathrm{w}$ okresie nowożytnym lub nawet współczesnym (XIX w.). Naprawy te wykonywano jednak podobnie niedbale, jak wzniesiono sam mur.

Mur zachował się w złym stanie. Jego centralna partia całkowicie się zawaliła na długości ok. $15-18 \mathrm{~m}^{19}$. Stopień zachowania substancji muru na tym odcinku jest niemożliwy do ustalenia ze względu na istniejące zawalisko. Można jedynie przypuszczać, że dolne partie budowli ocalały. Wskutek osunięcia się i odpadnięcia lica oraz znajdujących się pod nim warstw wypełniska, mur o pierwotnej grubości, $(\mathrm{ok} .160 \mathrm{~cm}$ ) zachował się tylko miejscowo w południowej części, na długości ok. $30 \mathrm{~m}$, w dolnych partiach, do wysokości ok. 1,0-1,5 m ponad poziomem przyległego terenu.

Utrata lica pociągnęła za sobą niszczenie wypełniska, a zatem zmniejszanie wysokości i grubości muru do ok. 50\%, toteż obecnie jego grubość w tych partiach wynosi ok. $80 \mathrm{~cm}$.

Wysokość partii ceglanej jest niemożliwa do ustalenia. Jej rozbiórka nastąpiła

17 Sondaże i inwentaryzacja archeologiczna - M. Truszkowski, M. Kurdwanowski (październik 2017; opis wg wyników badania (G. Bukal, A. Kapuściński, październik 2017).

$18 \mathrm{Na}$ obecnej koronie zachowały się resztki cegieł. Wysokość partii kamiennej jest podobna jak wysokość zachowanego muru skarpy po przeciwnej stronie fosy. Wskazuje na to również duża różnica poziomów między obecną koroną muru, a poziomem terenu zachodniego przedzamcza, wynosząca ok. 1,8 m.

19 Przyczyną destrukcji muru było prawdopodobnie przede wszystkim bezpośrednie oddziaływanie czynników biomechanicznych; nasyp i sąsiedztwo muru porośnięte były przez wielelat zaniedbaną, nadmiernie rozkrzewioną po 1945 roślinnością niszczącą zaprawę, w następstwie czego wypadały okrzeski i drobne kamienie, potem duże kamienie licowe, pozbawione równomiernego podparcia. Interesujące jest, że kamienna partia muru skarpy fosy zachodniej, będąca podobną strukturą, eksploatowaną w podobnych warunkach znajdowała się w końcu XIX lub na pocz. XX w. w stosunkowo dobrym stanie, który nawet w około 100 lat później nie uległ istotnemu pogorszeniu, co zawdzięcza prawdopodobnie staranniejszemu wykonaniu, zachowaniu partii górnej muru oraz braku roślinności; zob.: Steinbrecht, op. cit., Taf. 15 - rysunek inwentaryzacyjny muru skarpy wykonany zapewne w końcu XIX w.; Bukal, Kapuściński, Problematyka... op. cit., s. 22. Przyczyną zawalenia muru (w 1993 r.) było zapewne wybudowanie (w 1960 r.) budynku mieszkalnego w odległości zaledwie o 6,5 m od muru. 
przypuszczalnie wraz z rozbiórką murów zamku w końcu XVIII w. Obecnie korona jest prawie całkowicie przykryta współcześnie ukształtowanym nasypem ziemnym o grubości ok. 1,5 m, wywierającym na osłabioną konstrukcję muru silne parcie grożące budowli niebezpieczeństwem. Czynnik ten nie występował w przypadku murów wolnostojących, ułatwiając zaprojektowanie zabezpieczeń i obniżając ich koszty.

Stan muru oraz warstwa nasypów nie wykazują długotrwałego odziaływania wód ${ }^{20}$.

W bardzo podobnym stanie jak mur wschodni jest też mur od strony zachodniej.

Jako rozwiązanie ${ }^{21}$ zaproponowano usunięcie naziomu obciążającego górną partię muru, możliwie kompletną odbudowę dolnej partii lica, częściową odbudowę wypełniska powyżej, jednakże bez dążenia do odtwarzania oryginalnej grubości muru a poprzez utworzenie rodzaju chroniącego je płaszcza. Do konsolidacji struktury zaproponowano również wykorzystanie systemu nierdzewnych kotew i linek stalowych. Aby powstrzymać obrót muru zaproponowano system kotew gruntowych, a w celu wzmocnienia podłoża jego miejscowe zeskalanie.

Wolno przypuszczać, że realizacja tak przewidzianych zabezpieczeń pozwoliłaby zabytek zachować w pełni jego autentyzmu.

Pojawia się jednak problem szacowanych kosztów przedsięwzięcia, które obecnie znacznie przekraczają możliwości miasta, nawet w odniesieniu do najlepiej zachowanego odcinka (ok. $50 \%$ długości) muru.

Alternatywą dla zaproponowanych rozwiązań mogłoby być dopuszczenie sytuacji, w której mur będzie popadał $\mathrm{w}$ ruinę dalej, w naturalnym procesie niszczenia i wówczas należałoby rozwiązać tylko wynikające z tego kwestie bezpieczeństwa ludzi oraz niefortunnie usytuowanej powyżej zabudowy. Być może rozwiązaniem kompromisowym byłyby częściowe rozbiórki górnych partii lub partii najgorzej zachowanych.

Choć nawet przy tak absolutnie „niekonserwatorskim” podejściu do problemu nie dałoby się uniknąć wykonania czysto współczesnych, niezbędnych zabezpieczeń osuwających się, pięciometrowych skarp.

W tym kontekście nie sposób jednak nie zauważać kwestii opłacalności i technicznej racjonalności podejmowania pewnych ratowniczych interwencji budowlano-konserwatorskich w odniesieniu do obiektów, których stan i okoliczności awarii nie gwarantują powodzenia przedsięwzięcia, a wartość zabytkowa - choć w omawianym przypadku niezaprzeczalna - nie uzasadnia ponoszenia nadmiernych kosztów.

20 Stałoby w sprzeczności z powszechnym poglądem o nawodnionej fosie zachodniej. Rzędne linii brzegowej Jez. Urzędowego na wysokości fosy wynoszą ok. 158,20-158,49 m nmp; rzędne dna fosy: 160,08-162,00 m nmp. ${ }^{21}$ G. Bukal, A. Kapuściński: Mur przeciwskarpy fosy zachodniej zamku w Człuchowie. Badania i koncepcja zabezpieczeń, mps. 2017. 
Zabezpieczenie i ekspozycja murów zamku w Człuchowie. Doświadczenia i nowe problemy

\section{Uwagi końcowe}

Zabezpieczanie i ekspozycja ruin i reliktów architektury ma w historii konserwacji zabytków długą historię, jak również obszerną literaturę przedmiotu, toteż trudno tu formułować wnioski - zwłaszcza dotyczące problemów architektoniczno-budowlanych - które pokazywałyby nowe punkty widzenia lub proponowały uniwersalnie ważne rozwiązania problemów.

Mechanizmy niszczenia są doskonale znane; przynajmniej na poziomie praktycznym. Choć nie wszystko daje się przewidzieć...

W procesie inwestycyjnym obejmującym zabytki w stanie ruin - zwłaszcza większe, nierozpoznane zespoły - należy szczególną uwagę poświęcić fazie przedprojektowej, zwykle możliwej do zorganizowania przez inwestora, bez konieczności uzależniania się od finansowania zewnętrznego, a obejmującej:

- rozpoznanie obiektu (badania archeologiczne, historyczno-architektoniczne, stanu technicznego i konserwatorskie);

- realistyczne określenie celów i zakresu wykonalności zadań;

- wykonanie wstępnych projektów (studialnych i koncepcyjnych);

- oszacowanie kosztów;

- wybór rozwiązań, stanowiących podstawę dla projektów i ich realizacji.

W przypadkach bardziej skomplikowanych - zapewnienie niezależnego opiniowania przedstawianych projektów, do czego inwestorzy (np. urzędy gminne czy miejskie) nie dysponują odpowiednio wykwalifikowanymi specjalistami.

Należy również zdawać sobie sprawę, że nawet umiejętne i staranne wykonywanie wszelkich prac zabezpieczająco-konserwatorskich może procesy niszczenia spowalniać, ale nie zatrzymać, ponieważ w pełni skuteczne, długotrwałe zabezpieczenie materiału ceglanego i spajających budulec zaraw wapiennych, narażonych na wpływy zmiennego, wilgotnego klimatu północnej Europy nie jest możliwe.

Z drugiej strony - procesy niszczenia są częścią natury, a umiejętnie powstrzymywane zachodzą przez stulecia lub dłużej. Świadomość tego nadaje sens praktyce konserwatorskiej. 

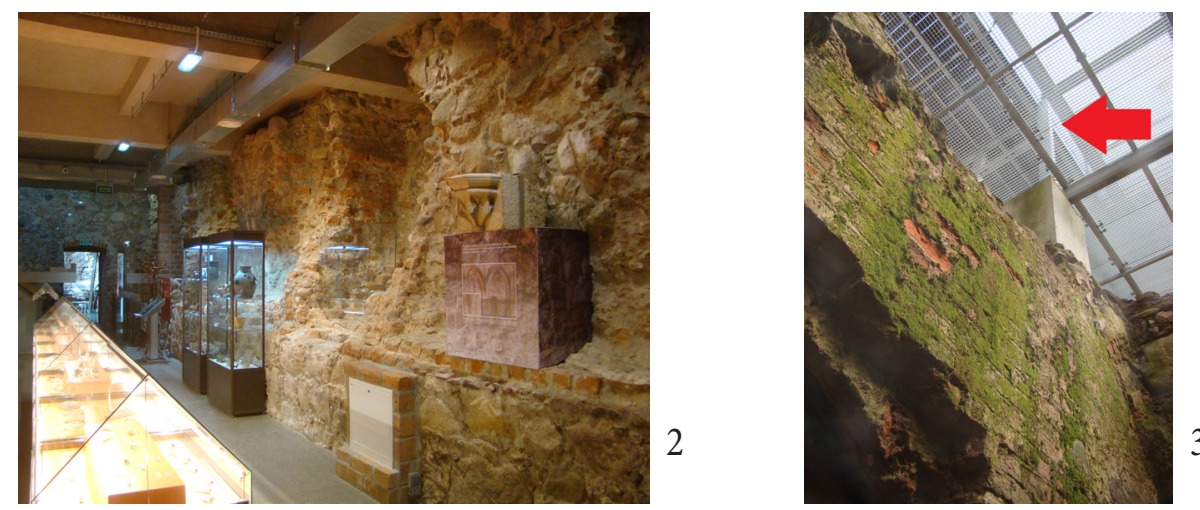

Ryc. 2 Eksponowany we wnętrzu mur przyziemia skrzydła północnego. Widoczne wnęki lunet i żelbetowy strop (2018, fot. autora)

Ryc. 3 Wnętrze piwnic skrzydła południowego. Nieuzasadnione skrócenie połaci dachowej (do miejsca oznaczonego strzałką) powoduje zamakanie ściany (2018, fot. autora)

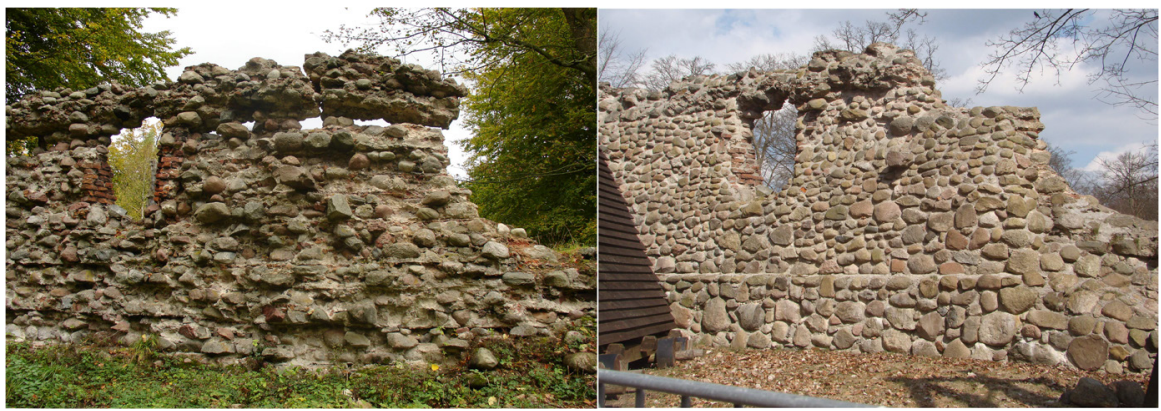

Ryc. 4 Fragment muru „Kujaw”: utrata „dramatyzmu” ceną za zachowanie zabytku... (2007, 2014, fot. autora)

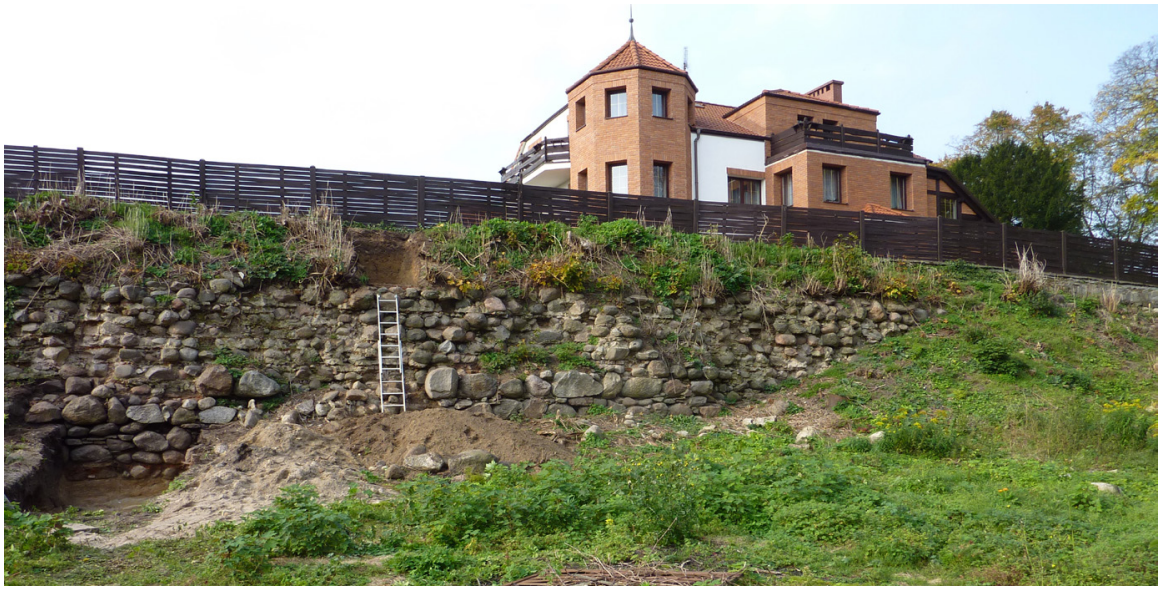

Ryc. 5 Mur skarpy przedzamcza zachodniego. Odkrywka archeologiczna po lewej stronie ukazuje głębokość posadowienia; widoczny budynek - prawdopodobna przyczyna zawalenia długiej partii muru (2017, fot. autora) 